\title{
Health Institutions, Temporary Work Agencies, and the Mobility Power of Nurses'
}

\section{Hege Merete Knutsen²}

Professor, Department of Sociology and Human Geography, University of Oslo, Norway

\begin{abstract}
The objective of this article is to explore how the mobility power of nurses (the ability to move between employers or leave the labor market) contributes to changing relations between health institutions and temporary work agencies in the Norwegian welfare state. Based on case study as the research strategy, the article contributes to the political economy of labor relations approach and the debate over the role of TWAs and temporary nursing in the health sector. The mobility power of Swedish nurses who shift from agency nursing to direct temporary nursing in health institutions (bank nursing) partly explains the constrained growth of agency nursing in the Norwegian hospital sector. However, contracting flows of Swedish nurses to Norway since 2015 challenge internal labor hire and could make health institutions more agency-dependent in future. The data employed are semi-structured interviews, official statistics, reports, and news clippings.
\end{abstract}

\section{KEYWORDS}

Mobility power / Nonway / nursing / personnel pools / temporary work agencies

\section{Introduction}

ealth institutions in many countries suffer from nurse shortages and temporary work agencies (TWAs) have gained a foothold in this part of the labor market (Jansson \& Engstrøm 2017; OECD 2015; Purcell et al. 2004; Seo \& Spetz 2014). Research on TWAs tend to focus on either the relationship between the client firms and TWAs in light of the client firms' need of flexible labor (see Svalund 2018) or the experiences of agency workers, such as the effects of agency work on their work-life balance, opportunities for permanent employment, or precariousness at work (De Ruyter et al. 2008, Gottfried 1992; Tailby 2005). However, in line with the political economy of employment relations approach, both client firms and TWAs are embedded in contingent relationships with each other and with labor and these relationships have to be understood in the political, regulatory, and economic contexts that they take place (Coe et al. 2009; Jordhus-Lier et al. 2015; Purcell et al. 2004).

The objective of this article is to explore how the mobility power of registered nurses (hereafter 'nurses') contributes to changing relations between health institutions and TWAs in the Norwegian welfare state. Briefly put, 'mobility power' refers to the ability of labor to move between employers or leave the labor market (below). Labor can use its mobility power to pressure for better conditions by both threatened and actual exit from the workplace (Smith 2006). The article thus contributes to the political economy

\footnotetext{
${ }^{1}$ You can find this text and its DOI at https://tidsskrift.dk/njwls/index.

${ }^{2}$ Corresponding author: Hege Merete Knutsen. E-mail: h.m.knutsen@sosgeo.uio.no.
} 
of labor relations approach. It does not only bring labor as sentient beings into the analysis, but it also puts labor and its mobility power at the center stage and explores what new insights this angle brings to nurse staffing in the health sector. The theme is actualized by signs of constrained growth of agency nursing and greater emphasis on bank nursing (internal labor hire) and personnel pools in Norway (Aanerud 2015; Brandshaug 2017; the Health Enterprises' Procurement Service, HINAS, in Dolonen 2018; SSB 2011-2014; SSB 2015-2017; Stavanger Aftenblad 2010). This changing relationship between health institutions and TWAs will form the empirical backbone of the analysis.

The concept of bank nursing requires operationalization. In a case study of the UK National Health Service (NHS), bank nursing refers to internal hire of temporary nurses by NHS trusts as on-call or casual workers, whereas agency nursing refers to external hire of nurses from commercial agencies (Tailby 2005). In the case study from Norway, the respondents never used the term bank nursing, but (personnel) pools. They operated with different types of pools and there could even be a pool of permanently employed nurses to be shifted between wards. In the analysis, the concept of bank nurses only applies to internal hire of temporary nurses; whether on-call or casual; and whether initially recruited by the staffing center or a ward. Any nurse hired on a temporary basis had to sign a contract with the hospital staffing center.

There seems to be few in-depth studies addressing TWAs as providers of temporary nurses in countries other than the UK and the USA. Both countries are characterized by liberal industry regulation and liberal labor market regulation with relatively few constraints on the TWAs (Coe et al. 2009). A case study from the Norwegian welfare state can thus shed further light on accessing nurses through TWAs. The Norwegian welfare system is universalistic and generous. Income tax and full employment are important to finance the system, as is full employment to reduce the costs of it. Industrial relations are tripartite with centralized mechanisms of wage-setting, strong unions, and a compressed wage structure. Similar to Sweden, but unlike the UK and the USA, Norway combines a highly regulated labor market with liberal industrial regulation (Coe et al. 2009; Knutsen 2014).

In Norway, private employment exchange and contracting out of labor was not legalized until 2000 and permanent employment is the 'rule' as stated in Lovdata (2014). Furthermore, the Norwegian health sector is primarily a public sector. ${ }^{1}$ Nurses are important in providing health services at the level that the population expects from the welfare state, and welfare services at this level are in turn important to maintain the welfare state. These factors may constrain agency nursing and affect whether and how nurses resort to mobility power.

Addressing the objective of the article, the analysis is structured around three research questions and a transversal theme: First, what experiences motivate the nurses for agency nursing and bank nursing and how do they use their mobility power in this respect? Second, how do health institutions experience agency nursing and how does this affect their strategies to access nurses? Third, how do the TWAs respond to the strategies of the health institutions and the mobility power of nurses and what could be the implications of this for nurse staffing in the health sector? The context-specific factors in Norway affecting motivations and action is the transversal theme.

The analytical framework presents previous literature on why health institutions resort to agency nursing and bank nursing and how TWAs may respond. I then explain the concept of mobility power and how I am going to use it in the analysis. After 
presenting the methods, I turn to the Norwegian case. I start with a short background section on the labor market for nurses and the available data on the constrained growth of agency nursing. After analyzing the experiences and mobility power of the nurses, I continue with how health institutions experience agency nursing, their internal measures to deal with nurse shortages, and implications of this for their relations with the TWAs. The last part of the analysis addresses how TWAs consider their relationship to the health institutions and respond to the nurses' mobility power. The conclusions sum up the main empirical findings, noting what insights the analytical framework incorporating attention to mobility power and the Norwegian welfare state can contribute.

\section{Analytical framework}

\section{Previous studies}

\section{Agency nursing from the angle of the health institutions}

Achieving numerical flexibility by externalizing employment relations to cut costs has not only gained considerable attention in the lower end of the labor market (see Berglund et al. 2017), but also in the high-skill end of the labor market, agency nurses are hired to ensure numerical flexibility and reduce costs (Houseman et al. 2003; Seo \& Spetz 2014).

Houseman et al. (2003) showed that agency nurses in the US health sector covered for workload variability, absences, and temporary vacancies. The health sector also turns to TWAs to deal with nursing shortages as a long-term and structural problem of recruitment and retention (Purcell et al. 2004). Statistical data from California 1996-2002 revealed increasing demand for agency nurses during periods of nursing shortages. Demand rose with the number of patients cared for and increases in patient-care demand and the level of benefits paid to regular staff (Seo \& Spetz 2014). Elsewhere in the USA, health managers did not find agency nursing cost-effective, and they expressed quality concerns about this type of nursing. Several hospitals reduced their use of agency nurses and turned instead to bank nurses. These received higher wages than regular staff, but less than agency nurses (May et al. 2006). Similarly, a case study of the NHS in the UK shows that bank nursing escalated in the 1990s as an alternative to agency nursing, due primarily to the high cost of agency nursing (Purcell et al. 2004). However, the NHS still spends large amounts on high-cost agency nursing (Royal College of Nursing \& HCL nursing 2016).

A quantitative study of agency staffing (nurse aides, licensed practical nurses, and registered nurses) in US nursing homes found that health managers saw more disadvantages than advantages (Castle 2009). The most frequently reported disadvantages included higher expenses for and lower productivity of agency staff than regular staff, the need for supervision of agency staff, disruption of ward routines; psychological distress, lack of continuity of care, and practices unfamiliar to residents. Agency staffing was deemed advantageous as regards staffing levels and being able to obtain personnel as and when required. These findings are in line with previous studies of agency staffing in hospitals and nursing homes (see Castle 2009). In a qualitative study at a Swedish hospital, agency nurses were characterized as competent, ambitious, generous, and 
social, and important for relieving regular nurses of the burdens of overtime and extra work. However, agency nurses also increased the workload of the regular nurses, who are the ones that know the routines, procedures, and equipment in the unit (Jansson \& Engström 2017).

Contrary to the conventional discourse on agency work, several studies contest that flexibility by agency nursing is cost-effective, but they argue that agency nursing is important to ensure 'adequate' staffing levels. Bank nursing is preferable because it offers flexibility at a lower cost. How the preferences of the nurses affect staffing strategies is not a topic in the above studies, except for Purcell et al. (2004).

\section{Agency nursing from the angle of the nurses}

Nurses use agency nursing to earn higher wages and escape a stressful working life with increasing workloads, pressures to work extra hours, and inconvenient shifts in regular employment. First, agency nurses can work closer to patients than regular staff. Second, they are exempted from many tasks related to routines and longer-term planning and development in the units where they are placed. Third, they can more easily distance themselves psychologically from patients and workplaces when the workday is over (De Ruyter et al. 2008; Jansson \& Engström 2017; Tailby 2005). Moreover, agency nursing can be a strategy to obtain a better work-life balance and a strategy when career prospects in regular employment are limited (Tailby 2005). These factors reflect negative experiences with regular employment and that agency nursing can be a result of financial and stress-related need.

Previous studies also accentuate the downside of agency nursing. Unpredictability regarding access to work, where and what type of institution to work for next, and short-notice assignments make agency nursing stressful (De Ruyter et al. 2008). Dual control by managers in the workplace and managers in the TWA adds to this (Gottfried 1992): Agency nurses feel that they must continually make their contributions and results visible in the workplace to get their contract renewed, and fear that their TWA manager may not be informed about their achievements (Cicellin et al. 2015). Other studies show that agency nurses feel themselves looked down upon by regular nurses and that they get more difficult workloads, having to take shifts and tasks unpopular among regular staff (Cicellin et al. 2015; Royal College of Nursing \& HCL Nursing 2016). Thus, nurses who want more predictable work than agency nursing and tasks closer to their original areas of expertise often find bank nursing preferable to agency nursing (Tailby 2005; Zampoukos et al. 2018).

\section{The strategies of TWAs}

TWAs have been studied as strategic and profit-seeking actors and powerful agents of labor market liberalization (Jordhus-Lier et al. 2015; Peck et al. 2005), taking advantage of and seeking to influence the regulatory context where they operate. Studying the global expansion of TWAs, Coe and colleagues explore 'the agency of the agencies' in relation to how national temporary staffing markets are produced in varying regulatory contexts (Coe et al. 2010, p. 1058; Jordhus-Lier et al. 2015). Unlike the UK and the 
USA, TWAs in the welfare state of Sweden have not been able to expand in the ways they would like, being subject to high entry barriers and a 'heavily regulated mainstream labor market' (Coe et al. 2009, p. 81). The largest TWAs, however, have been able to grow and protect their market shares within this context.

Studies of the agency of agencies in the health sector are difficult to find. The study of Purcell et al. (2004) is an important exception. When combining agency nursing with regular nursing became attractive to regular nurses in the UK, this exacerbated the problem of internal staffing. The NHS introduced bank nursing to reduce its dependence on TWAs and curb costs (Tailby 2005). Purcell et al. (2004) found the TWA that they studied vulnerable to the strategies of the NHS but able to adapt to shifting conditions, seeking 'to meet and influence the expectations of the temps' and 'obtain social legitimacy to ensure acceptance and survival' (2004, p. 706). The TWA thereby deepened its relationship (2004, p. 719) with the nurses, providing facilities for training and career advice, offering paid training and shared facilities with the nurses' union. Attempting to become 'indispensable to major employers', it focused on supplying specialist nurses for shortterm assignments (2004, p. 706). The findings inspire further research on the agency (capacity to act in their own interest) of the nurses in their relations with the TWAs and health institutions. Conceptualization of mobility power is an entry point for such studies.

\section{Mobility power}

Drawing on labor process theory, Smith (2006) introduces the concept of 'mobility power' in relation to the struggle between capital and labor and the double indeterminacy (uncertainties) of labor as willful agents. Within the capitalist system, employers strive for higher surplus values and higher and newer forms of work intensification. This requires compliance and consent by labor, and is a source of struggle between capital and labor. Labor power is seen as consisting of two elements: power over work efforts, and power to move between firms (mobility power). These are the sources of work-effort indeterminacy and mobility-effort indeterminacy (Smith 2006). In its role of employer in the public sector, the state represents capital.

Work-effort indeterminacy concerns struggles over factors like wages, working conditions, and work-pace. At the analytical level addressing the agency of the actors, the struggles are divided into work-effort bargaining and mobility-effort bargaining. Workeffort bargaining is expressed in acts such as go-slow and withdrawal of commitment, collectively organized by actors such as work groups or the trade union. Employers meet this with increased stringency and control (Smith 2006).

Mobility-effort bargaining takes the forms of withdrawal, threatened exit, and increased job search. These acts are mainly individual and informal. Workers can threaten to quit, seeking to achieve better workplace conditions, or may exit to escape problems. At this level of analysis, mobility power refers to the ability of workers to move between firms. To weaken the mobility power, employers may try to retain workers, for example, by rewards and career developments that increase the cost of leaving. While firm-specific skills that cannot be applied elsewhere might raise the cost of leaving, building skill-depleted jobs could make it easier for the employer to access larger labor markets. Using agency workers is another option for managing mobility when there are problems in securing enough permanent staff (Smith 2006). 
Work-effort bargaining and mobility-effort bargaining largely overlap Hirschman's (1970) conceptualization of voice and exit and the way this actor-based approach is applied in management studies (see Kiil \& Knutsen 2016). In short, exit may follow if voice does not succeed, and threatened exit lies in the borderline between voice and exit. Similarly, in the mobility-power approach, high labor turnover and threatened exit strengthen the leverage of workers in work-effort bargaining. The same applies to shortage of labor, which makes recruitment difficult. The article thus applies a broad concept of mobility power adding the ability to leave the labor market.

An advantage of the mobility-power approach is that it is more concerned with what workers may achieve collectively for themselves than the Hirschman-approach (Kiil \& Knutsen 2016). It is, however, important to note that power to exit does not necessarily lead to a positive outcome for the workers. Neither the mobility-power approach nor the Hirschman-approach are concerned with what those who leave the workplace obtain for themselves.

Wright (2000) and Silver (2003) distinguish between the structural power and the associational power of labor. Mobility power (Smith 2006), which is based on demand and supply in the labor market, is a form of structural power. Associational power is based on efforts and support initiated by organizations and alliances. Work-effort bargaining (Smith 2006) can benefit from associational power when actions are collectively initiated, for instance by trade unions. Whereas Smith (2006) acknowledges that quitting can be a source of conflict involving a number of actors, the trade union among them, he does not delve into how mobility power and associational power may affect each other, which will be addressed in the analysis.

Low wages and poor working conditions among nurses have led to a surge in unionization. However, militant actions and strikes as elements of voice have to a large extent been regarded incompatible with their professional work, which requires them to hold back on resentments and emotions. Strikes among nurses are also often restricted by regulation (Bergene \& Egeland 2016; Kiil \& Knutsen 2016). This makes nursing a particularly interesting occupation for the study of how mobility power affects the relationships between TWAs and client institutions.

\section{Methods}

This article employs case study as the research strategy (Yin 2014), and uses data collected for the research project 'The impact of temporary work agencies on the politics of work', funded by The Research Council of Norway, Ref. 227021/H-20. The data material consists of 36 semi-structured interviews conducted between June 2014 and August 2017, comprising altogether 43 respondents. ${ }^{2}$ Interviews were conducted in five hospitals (eight managers and three nurse leaders), and five nursing homes (five managers), at Hospital Partner (one manager), three Norwegian TWAs (six managers), and with 20 Swedish nurses. Swedish nurses are the largest group of foreign nurses in Norway.

Only in one TWA and one hospital, two or more managers and leaders were interviewed together. The interviews lasted between half an hour and more than two hours, most of them exceeded one hour. The nurses were recruited through professional networks, Facebook and the Internet, and by help of the snowball method. Most of the 
nurses, two of the hospital managers, the manager at Hospital Partner, and three of the managers in the nursing homes were interviewed by telephone. Telephone interviews, sometimes followed up with e-mail correspondence, functioned well judging from the amount and relevance of the data obtained.

The health institutions were asked about challenges they face in terms of staffing, the internal solutions they resort to and experiences with these, and their experiences with agency nursing. The nurses were asked about their migration history, their experiences with temporary work, both for TWAs and for the health institutions directly, and how they respond to what they perceive as inferior employment and working conditions.

The TWAs were asked about how they access nurses and the employment conditions they offer, their experiences catering to hospitals and nursing homes, respectively, what the health institutions and nurses require from them, and experiences of being included in and operating outside the HINAS agreement. ${ }^{3}$ HINAS was established in 2003 by the regional health enterprises to coordinate procurement of goods and services for the hospital sector. The HINAS agreement dating back to 2009 is a national framework agreement with selected TWAs on labor hire to the hospital sector. The objective is to curb escalating costs and ensure high-quality services.

The interview data are supplemented with official statistics, reports, and news clippings. The interviews have been analyzed manually, each transcript critically examined several times searching for differences in the experiences of the various categories of actors and how this relates to the secondary data sources and the literature review. References to the individual respondents below are intentionally vague, as they were promised anonymity. TWAs and health institutions are not numbered to prevent that cross referencing might reveal their identity.

\section{The Norwegian case}

\section{Background}

While the health sector employs some 95,000 nurses (SSB, 2016), ${ }^{4}$ it is currently short of 4000 nurses, including 400 specialist nurses (NAV 2017). By 2035, the nursing shortage may be as high as 28000 (Stølen \& Texmon 2012). It is difficult to recruit nurses to fill vacancies, and there is a need for substitute nurses to cover for sickness absence, parental leave, and holiday seasons when many permanent staff are on leave (Berge et al. 2011; Gautun et al. 2016).

Wages for nurses are low compared to other economic sectors in Norway; there is under-staffing and inconvenient shifts and rota work. ${ }^{5}$ Another disincentive is the difficulty for many nurses in getting full-time positions because of shift-work technicalities. About half of Norway's permanently employed nurses hold part-time positions (The Research Council of Norway 2014). Moreover, many specialist nurses are due for retirement 2015-2025, but not enough new specialist nurses are being trained (Dolonen 2015).

Based on the interviews with the nurse leaders in the hospitals and the nursinghome managers, nurses use their mobility power: Some leave unattractive workplaces for workplaces with better conditions and some leave the profession. One of five nurses 
trained in 2004 was not working in the health sector ten years later (Skjøstad et al. 2017). Agency nursing is one of the strategies the health institutions resort to in the tight labor market.

\section{Constrained growth of agency nursing}

After the legalization of private employment exchange and contracting out of labor in 2000, agency nursing reached a peak of more than 3000 nurses in 2009. The number declined to 1566 in 2014, and further down to 1309 in 2016 (Berge et al. 2011; SSB 2015-2017). ${ }^{6}$ However, these figures do not indicate the full significance of the TWA sector in the Norwegian labor market for nurses. First, the statistics cover only nurses in TWAs that operate offices in Norway. Second, the data refer to a representative week in November, and not in the summer, when the demand for substitutes is highest. Although the TWAs report on education not occupation, one may assume that the TWAs supply 'so to say, all of them' to the health sector (manager, TWA).

Figures from Hospital Partner on the number of hours worked by agency nurses in the hospital sector as part of the HINAS agreement indicate a recent decline in the use of agency nurses but to a lesser extent than the number of agency nurses above. The number of hours increased from 559,568 to 668,558 for 2010-2013, gradually declining to 496,157 in 2016 (Ministry of Health and Social Care 2016; Hospital Partner 2017). Expenditure on agency nursing reached NOK 436 million (Euro 48 million) in 2016 and has been stable from 2013 to 2016 (HINAS in Dolonen 2018).

Moreover, the Confederation of Norwegian Enterprise (NHO) reports a sharp decline in the number of hours invoiced in 2009 and further decline from 2013 by its TWA member companies in the health and care sector. That category includes hospitals as well as the municipal health sector, and not only nursing staff (NHO Service 2017). According to one of the TWA managers, there are a few smaller, local TWAs in the municipal sector that are not NHO members.

Although the available statistical data have their limitations, one of the characteristics of the relationship between health institutions and TWAs are signs of decline and constrained growth in the use of agency nurses since the peak year of 2009. Another important feature is the significant drop in the number of Swedish agency nurses in Norway, from 1629 in 2010 to 551 in 2014 and further down to 202 in 2016 (SSB 2015-2017). In contrast, the number of immigrant and nonresidential Swedish nurses increased from 1835 to 2199 between 2010 and 2014 (SSB 2011-2014), underscoring the tendency to bank nursing. For 2012-2016, expenditure on agency nursing in the hospital sector equals 530 nurse work years a year, or $1.7 \%$ of the total number of nurse work years in the hospitals (based on HINAS in Dolonen 2018).

According to the Work Environment Act (WEA), it is permitted by law to hire out labor, but hiring in labor is permitted only when the work is of a temporary nature, and as a temporary replacement for another person. Additionally, the Act permits temporary work in cases where there are considerable seasonal fluctuations in the amount of work to be done, and when there are major unpredictable increases in ordinary work tasks. The restrictions on hiring in labor also apply to labor from TWAs (Lovdata 2014). In 2008, regulations on wages and working conditions in public contracts stated that the client firm shall require that the employees of their contractors and 
subcontractors get wages and working conditions not inferior to the applying national tariff agreement, or what is otherwise normal for the place and position in question (Lovdata 2008).

Despite the WEA and the sharpening of the regulations in 2008, the engagement of TWAs in the health sector seems to have thrived the first 10 years after the legalization of private labor hire (Dahle 2011). In subsequent years, media coverage of illegal working conditions and wage conditions may have contributed to sharpen regulatory implementation. Following a scandal in an Adecco nursing home in 2011 (see Bergene \& Egeland 2016), TWAs came under more pressure to monitor and reduce overtime and it became more difficult for the agency nurses to get the amount of overtime that they wanted. According to the interviews with the Swedish nurses, the manager of a hospital staffing center, and a TWA manager, it was still relatively easy to get overtime for bank nurses in the hospital sector, making bank nursing more attractive. This sharpened implementation of the labor regulations has thus favored bank nursing.

\section{Agency nursing, bank nursing, and the mobility power of the nurses}

The Norwegian Nurses Organization (NNO) was initially against the legalization of private employment exchange and contracting out of labor. Not being able to prevent it, the organization changed strategies in 2001-2002 and encouraged agency nursing for those who wanted to switch jobs to obtain higher wages and more flexible working hours. The objectives were to keep the membership base and use agency nursing as a lever to increase wages for the permanently employed (Bergene \& Egeland 2016; Dahle 2011). The NNO managed to establish tariff agreements with nine TWAs in 2001-2002 resulting in a good increase in the wages of all nurses in 2002 (Skjælaaen 2010). This illustrates how mobility power and associational power may enforce each other. However, one of the TWA managers argued that the agreements became too expensive to the TWAs and were thus not renewed.

Since 2011, the NNO has taken an active stand in the public debate that the large amount of public money spent on temporary nurses is better spent on permanent positions (Dolonen 2018). The political Left frequently raises the issue in Parliament (see for instance Ministry of Health and Social Care 2016). The counter argument among the TWA managers is that the share of nurse work years in agency nursing is too low to challenge permanent employment.

Agency nursing has not become particularly attractive among Norwegian nurses. Less than 1\% of the Norwegian nurses work for TWAs (Dahle 2011; SSB 2015-2017). Pensions are better in the state and municipal sector, although it is possible to negotiate higher wages from TWAs. The manager of a hospital staffing center explains that regular nurses can easily get additional work and well-paid overtime, if wished, in the institutions where they are employed. Such additional work is included in pension calculations. Unlike findings from the UK (De Ruyter et al. 2008; Tailby 2005), the social security system and labor regime of the Norwegian welfare state may to some extent act as a barrier to agency nursing. In the UK, agency nursing could be a way to avoid overtime without overtime payment. However, the financial benefit of agency nursing decreases when sick pay, leave entitlements, and pensions in regular positions are accounted for (De Ruyter et al. 2008). 
The manager of a hospital staffing center and nurse leaders at the hospital wards think that those Norwegian nurses who choose to work for TWAs often do so in order to familiarize themselves with the labor market before getting a permanent $100 \%$ position, and to avoid having to work every third weekend. For the Swedish nurses who want to combine working time flexibility with more predictability in when, where, and how much to work, bank nursing seems to be a better option than agency nursing. Voluntary part-time in a permanent position offers less flexibility than agency nursing and bank nursing but is a solution for those who want more predictability. This is not to miss that involuntary part-time has become a barrier to recruit and retain nurses in the Norwegian health sector (The Research Council of Norway 2014).

\section{Foreign temporary nurses}

Because of the limited interest in agency work among Norwegian nurses, TWAs based in Norway rely mainly on immigrants or nonresidential nurses from other countries than Norway. This group constituted 77\% of the agency nurses in 2016 (SSB 2015-2017).

According to the respondents in the hospital sector, the labor market for agency nursing in this sector is predominantly Scandinavian, mainly due to strict language requirements. In the hospital sector, TWAs deliver mostly Danish nurses, whereas bank nurses are mainly Swedish. The mangers of the hospital staffing centers explain that Swedish and Danish nurses are desirable in Norway because of the close similarities in language and culture, as well as their nursing skills.

The Swedish nurses in this study use their mobility power to leave the Swedish labor market altogether, or they combine a regular, and sometimes part-time, position in Sweden with temping in Norway (Kiil 2014). They go to Norway to escape the lower wages, demanding work-pace and bureaucratic routines that steal time away from nursing in Sweden. Their dissatisfaction started with the introduction of new public management in the health sector in the late 1980s. Subsequent financial crises have worsened their working conditions and frustration with individual wage setting (Kiil \& Knutsen 2016). These motivations, as well as the combination of regular and temporary work, resemble the case of NHS nurses in the UK (De Ruyter et al. 2008; Purcell et al. 2004; Royal College of Nursing \& HCL Nursing 2016).

The Swedish agency nurses use their mobility power in Norway too. The HINAS agreement (above) lists the TWAs from which Norwegian hospitals may hire health personnel. The prices increase the further down the lists the hospitals must go to get access to persons with the required expertise. If the TWAs in the HINAS agreement are unable to deliver, the hospitals may use the spot market, where prices are much higher. Swedish agency nurses tell that they can take advantage of this to 'agency-jump' for higher wages and better working conditions down the list. Being in high demand, they prefer such 'agency jumping' to payment between assignments, which is also the experience of TWA managers. While TWAs at the bottom of the list benefit, it increases the cost of agency nurses to the health sector.

The fact that many Swedish nurses have switched to bank nursing is another example of their mobility power. Bank nursing has become popular for several reasons: Although hourly wages may be lower in bank nursing, the Swedish nurses appreciate the predictability of being able to fill their time in Norway with work, and bank 
nursing offers good opportunities for extra work with overtime compensation. That they often return to the same health institution and ward whenever they go to Norway means continuity and familiarization with the workplace. They then feel that they can contribute more to the workplace and gain greater acceptance among the regular staff. Another advantage is to avoid the hassles of shifting from workplace to workplace in different geographical areas of Norway (Swedish nurses). The arguments concerning the hassles of agency nursing are similar to findings in the UK (De Ruyter et al. 2008; Tailby 2005).

The mobility power of Swedish nurses has contributed to higher wages for nurses in Sweden and high bonuses for nurses who agree to postpone their summer holidays. In addition to this, the value of the Norwegian krone started to decline in 2014 (Kiil $\&$ Knutsen 2016). The Norwegian labor market has become less lucrative and Swedish nurses demonstrate their mobility power by 'returning' to the Swedish labor market, as reflected in the declining number of Swedish agency nurses in Norway (SSB 2015-2017 above). Moreover, the mobility power that the 'remaining' Swedish bank nurses get when a large number has left enables them to set specific demands, like maximum 4-5 days of work but with extra shifts, to get the most out of their time in Norway, as explained by one of the nurse leaders in a hospital ward.

The Danish financial crisis in 2008 led to unemployment and the Danish Nurses Council (DNC) encouraged nurses to find work abroad, either by TWAs or directly. ${ }^{7} \mathrm{~A}$ number of Danish TWAs have signed agreements with the DNC on wages, paid travel (time and expenses), accommodation, and insurances. ${ }^{8}$ Moreover, one of the TWA managers claims that the Danish nurses can earn more if they are posted by a Danish TWA than if they are directly employed in Norway. The role of the DNC exemplifies how associational power enables mobility power.

Norway is a wealthy country with high income from its oil and gas resources and has thus been more resilient to financial crises than Sweden and Denmark. This explains why Norway can benefit from temporary nurses from the two other Nordic welfare states.

\section{Experiences and strategies of the health institutions}

Both before and after the institutionalization of external labor hire from TWAs, Norwegian health institutions have employed various measures for dealing with shortages: small part-time positions, temporary positions, on-call substitutes and holiday extras, as well as overtime and extra work among the regular staff, to secure access to nurses. Health workers may also step in for absent nurses (Dahle \& Midthus Østbye 2011; Gautun et al. 2016).

Agency nursing is referred to as the choice of last resort by the respondents both in the hospital sector and nursing homes. The main objections to agency nursing are that high costs and discontinuity in personnel can impair the quality of nursing. To illustrate this, nurse leaders explain that the median hourly pay for a full-time specialist hospital nurse in 2017 is NOK 283 per hour, ${ }^{9}$ whereas a specialist agency nurse might cost NOK 700-800 an hour 'all inclusive' (wages, margins, travel, and accommodation). According to the head of a ward with general and specialist nurses, an agency nurse would cost NOK 5000-8000 per shift. 
It is the wards that must accommodate the cost of agency nurses in their tight budgets. It thus happens that wards occasionally decline to take the agency nurses offered by the staffing centers. Leaders at the hospital-ward level and a manager at a hospital staffing center confirm this. One nurse leader in a hospital ward spoke of agency nursing as waste of scarce resources: directly employed nurses cost less, and provide greater continuity. Another nurse leader mentioned problems like lack of familiarity with the internal routines, and that agency nurses need time to acquaint themselves with the new workplaces, learning new routines and practices, before they can work independently, which affects both the productivity of the nurses and the quality of work. This is in line with findings from other countries (Castle 2009; Jansson \& Engström 2017; May et al. 2006).

Unpredictability concerning who the institutions get and whether the agency nurses can get down to work immediately is of great concern: 'If we get the wrong person, this means a heavy burden on the others, as this person would need a lot of help with medication and reporting' (nurse leader, hospital ward). A nurse leader in a ward with many specialist nurses told that they use agency nurses who are new to the ward only from Monday to Friday, when there are many experienced nurses on duty. The problem is that they need agency nurses in the weekends too: 'Nurses on call who can cover during weekends and in cases of sickness absence are worth their weight in gold' (nurse leader, hospital ward). When the wards place their orders, they may ask for nurses that they know from before, but many may be competing for the same experienced nurses. Nurse leaders in wards in need of specialist nurses also argue that the best TWAs are those with the highest delivery capacity and that specialize in supplying specialist nurses. Unfortunately, these agencies are found further down the HINAS list and are expensive. It is a source of frustration that the TWAs cannot always deliver the type of nurses requested by the institutions, particularly as regards specialist nurses for hospitals. According to the nurse leaders in the hospital wards and the managers of the nursing homes, it can also be difficult for hospitals and nursing homes to get agency nurses on short notice.

Since 2003-2004, the hospital staffing centers to coordinate the use of agency nurses have become increasingly important in the direct hire of temporary nurses and establishment of personnel pools for bank nursing (Dahle \& Midthus Østbye 2007; Skjælaaen 2010). Pools have also emerged in nursing homes, but according to the managers, they are not primarily to replace agency nursing.

In a project launched by the government in 2010 to experiment with measures to reduce involuntary part time, establishing pools for permanently employed nurses was widely used in nursing homes. A nursing-home manager referred to this and told that representatives of health institutions discuss experiences with various pooling solutions that could be helpful in recruiting and retaining personnel as part of the 'big full-time choice'.

One nursing home gets long-term substitutes from a pool at the municipal level, using its own pool of permanently employed nurses to cover for short-term leave. Using their own pool is more efficient than on-call lists, in terms of continuity as well as administration. In addition, it offers better control of personnel use and thus less risk of using temporary nurses to such an extent that permanent employment must be offered. The manager claims that this nursing home has become less dependent on expensive agency nurses too. Based on secondary data, another nursing home explains '... [we] now have 
qualified personnel on fixed wages where we previously used assistants, overtime or external TWAs ...' (Brandshaug 2017, p. 3, author's translation). The costs of administering the pool are minimal compared with how much is saved on personnel expenses. Savings on personnel expenses and less use of TWAs are echoed in the interviews with managers of other nursing homes where this type of pool has been tried.

For cost-related reasons, continuity of personnel and to some extent predictability, the nurse leaders of the hospital wards and the nursing-home managers prefer regular nurses working extra hours, bank nurses, and other internal solutions to agency nurses, but the internal solutions are not sufficient to cover the nurse shortages. Hospital staffing centers say they would find it hard to manage without TWAs, especially in the summer: 'In the summer there is a war going on between the hospitals fighting for nurses' (manager, hospital staffing center). In addition, there is the problem of competition among hospitals in recruiting specialist nurses for vacant positions. In the nursing homes too, the managers argue that TWAs are good to have in the hour of need. More importantly, the manager of a hospital staffing center emphasizes that they must be careful not to undermine the TWAs with their own pool of temp nurses.

\section{Experiences and strategies of the TWAs}

Seen from the TWA sector, the public sector is both extremely price-conscious and requires proper working conditions and wages. The TWA managers appreciate the latter but complain that that the combination results in low margins for serious TWAs. The wide scope of the HINAS agreement makes it risky not to take part in it. Inclusion in the agreement, without any negative marks for performance, could also be an asset in the market. HINAS/Hospital Procurement has a reputation for being more qualityconscious than the municipal sector. However, some TWAs find that they can do better on the spot market or opt out because they find pre-qualification requirements and audit too cumbersome. Those that cannot comply have to find assignments for lower quality conscious institutions and small municipalities where control is laxer.

A further challenge is that hospitals in Norway started cutting on long-term hire of agency nurses already around the year 2005, to save money (Dahle \& Midthus Østbye 2007). According to one of the TWA managers, the resultant many one-day TWA commissions require considerable administration. They are not very attractive to agency nurses either, and Swedish nurses report that they use their mobility power to shift to bank nursing for more continuity in their assignments.

\section{Bank nursing}

Establishment of staffing centers and development of bank nursing have developed into a situation of competition and cooperation between the TWAs and the hospitals, as confirmed in one of the TWAs. The competitive element appears less distinctive according to the interviews with the nursing-home managers. The establishment of personnel pools is a more recent phenomenon and there is no 'HINAS agreement' here. However, also in this sector, cost and quality concerns make many nursing homes reluctant to use agency nurses. 
As argued by a manager in one of the TWAs, staffing centers and bank nursing do not represent the full solution to the staffing problems. The TWAs have expertise in obtaining nurses that can be hard to find, like specialist nurses and nurses that must be recruited from abroad; moreover, they can send them to different parts of Norway as and when required. The staffing centers follow procedures that make agency nursing more transparent, which the managers of the TWAs find positive. However, staffing centers, being an additional link in the supply chain, could lead to delays in accessing nurses. Moreover, last-minute orders are difficult to fill if the clients specifically request nurses they have used previously. This emerging problem of matching short-notice delivery and nurses with experience from the workplace exposes a structural challenge of agency nursing.

The huge shortage of nurses predicted for the coming years because of the growing elderly population is an important motivation for TWAs to remain in the market for temporary nurses. One TWA has opted to remain in the market until demand picks up, serving both the hospital sector and the municipal sector. Another manager in a TWA that is deeply involved in supplying the municipal sector explains that their choice is a result of what the nurses they access can do and want to do. Hospitals require longer work experience and more advanced language skills. However, with the increasing demand for long-term assignments in hospitals in more peripheral areas, this is also a promising market segment: 'Clients are in enormous need [of nurses]. This [the health sector] is the right place to be' (manager, TWA).

\section{Responding to mobility power}

Based on the interviews with the TWA managers, the difficulties in recruiting Norwegian nurses to the health sector, together with the declining participation of Swedish nurses in the Norwegian labor market have prompted TWAs to search for nurses in Southern and Eastern Europe. A TWA pursing this strategy also provides longer and better language training and thereby deepens its relationship with the nurses. According to the TWA manager, follow up at work by a contact person also deepens the relationship.

Another strategy involves tapping into the Norwegian labor market and motivating nurses who would otherwise leave nursing to remain, as well as motivating those who have left to return. A manager in a TWA that does this tells that the TWA seeks to deepen its relationship with the nurses, stressing the opportunities for a better work-life balance in its recruitment strategy: Nurses can avoid inconvenient shifts and decide themselves what/how many weekends to work. This strategy can be seen as a response to the Norwegian nurses' mobility power in dealing with some of the problems nurses have with working conditions in regular employment. The manager argues that the TWA does not want to compete with permanent employment, but seeks to offer different ways of being part of the labor market, thereby helping to solve the nursing shortage. However, somebody has to take the inconvenient shifts that the health institutions already struggle to staff. When agency nursing became attractive to nurses in the UK, this exacerbated the internal staffing problems of the NHS (Purcell et al. 2004). As yet, however, combining regular nursing with agency nursing does not seem to have gained much ground in Norway.

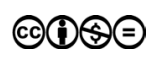




\section{Conclusion}

A relationship of cooperation and competition has evolved between Norwegian health institutions and TWAs with the growth of bank nursing. To the health institutions, this entails reluctant dependence on TWAs. Negative experiences with agency nursing regarding costs, productivity, and quality in the Norwegian welfare state parallel findings in international studies (Castle 2009, Jansson \& Engström 2017; May et al. 2006), suggesting that these problems are largely inherent to agency nursing as such.

Some health institutions in Norway have introduced bank nursing and personnel pools for permanently employed nurses seeing these as better solutions to their staffing problems than agency nursing. However, they also acknowledge that they still need agency nurses. Statistical data indicate that agency nursing in Norway has been leveling out.

Sharpening implementation of the regulations in the highly regulated Norwegian labor market together with higher requirements in the HINAS agreement reduce the TWAs room of maneuver. Another aspect of the Norwegian labor regime is that nurses earn higher pensions in the public-sector health institutions than the TWAs, which may limit their interest in agency nursing. Sharpening regulatory implementation resulting from media coverage and public pressure can be attributed to norms and values in the welfare state, but has not been examined as such in this study.

The constrained growth of agency nursing cannot, however, be fully explained without attention to the mobility power of the nurses. In the hospital sector, many of the Swedish nurses have used their mobility power to switch from agency nursing to bank nursing. To the nurses, bank nursing is less stressful and more predictable for filling their time in Norway with work and they can obtain more overtime. To the employers, bank nursing is more predictable and flexible than agency nursing. Bank nurses are ready at hand and willing to work extra hours when unexpected situations arise. In addition, it is less costly and ensures more continuity of staff.

The sharpest decline in the number of hours worked by agency nurses occurred between 2014 and 2016, coinciding with when Swedish nurses found it less lucrative to go to Norway. This indicates that the decline in agency nursing in the hospital sector is not only a matter of bank nursing and other hospital-internal measures to avoid expensive agency nursing: Access to foreign agency nurses is vulnerable to changing conditions and contingencies, in the country of temporary work itself, and in the homelands of the nurses. With attention to mobility power, the political economy of employment relations approach becomes more sensitive to context at different geographical levels, which is particularly important in an international labor market.

What is the future for the TWAs? Will they find themselves recruiting new temporary nurses, providing language training and introducing them to the Norwegian labor market, only to see the best of them 'disappear' into the banks of Norway's health institutions? The TWAs acknowledge the competition from the health institutions, but argue that existing and predicted nursing shortages make the health sector an interesting sector to operate in.

As in the UK case (Purcell et al. 2004), two of the TWAs react by deepening their relationship with the nurses, whether by providing more thorough language training and follow-up at work or by attracting Norwegian nurses by offering advantages such as a better work-life balance. Another strategy involves expansion within the municipal sector where requirements to TWAs and agency nurses are still lower than in the 
hospital sector. In some cases, the municipal sector has followed the hospital sector in establishing internal personnel pools, and a few municipalities have been seeking advice from Hospital Partner on contract negotiations with TWAs. These pools are established for better utilization of regular staff, not necessarily to attract temporary nurses, but they are reported to reduce expenditures on agency nursing.

The TWA sector is under pressure from two sides: the health institutions, through the HINAS requirements and the nurses, who with their mobility power, have stimulated bank nursing. Pressure notwithstanding, in view of the predicted demand for nurses by 2035, personnel banks and pools seem unlikely to render TWAs superfluous. Recruitment of non-Scandinavian nurses and language training will require resources that the health institutions do not have today. In 2017, applications to nursing colleges surged, but educational capacity must be expanded; moreover, it is too early to know whether the new generation of trained nurses will remain in the health sector. Important factors here are political priorities and budgetary allocations for higher wages, more fulltime positions, and less stressful working conditions that can attract and help to retain nurses in permanent positions. Attention to the mobility power of nurses underscores the importance of addressing these challenges, not only in order to retain the permanent nurses but also to attract temporary nurses when this is necessary.

In addressing mobility power as a form of structural power, it is also important to take associational power into account. The study has revealed how associational power enables and enforces the mobility power of Danish nurses who go to Norway. It has also showed how mobility power and associational power enforced each other in the Norwegian nurses' struggle for higher wages in 2002. The broad concept of mobility power including those who leave the labor market in addition to those who move between health institutions, provides a more complete understanding of the power being exercised on the employers.

Norway has benefited from the mobility power of nurses in countries with lower wages and less desirable working conditions. However, attention to nurses' mobility power also reveals how vulnerable health institutions become in their dependence on temporary foreign nurses if conditions in Norway or the countries of origin change. And, as argued by Purcell et al. (2004) in the case of the UK, if growing frustration with working conditions leads nurses to combine permanent positions with agency work, this may exacerbate the problems of internal staffing.

\section{References}

Aanerud, H. (2015). Vikarordning gir faste stillinger [Temp work arrangement gives permanent positions]. Available at: https://sykepleien.no/2015/12/vikarordning-gir-hundreprosent-stillinger (Accessed November 2017).

Berge, Ø. M., E. Falkum, Trygstad, S. C., Ødegård. A. M. (2011). Skaff oss dem vi trenger. Om arbeidskraftstrategier og forebygging av sosial dumping i helse og omsorg [Provide us with those that we need. About labour power strategies and prevention of social dumping in health and social care]. Fafo-rapport 2011: 20, Oslo: Fafo.

Bergene, A. C., Egeland, C. (2016). Intervention as union strategy? The strategies of the Norwegian Nurses Organisation in relation to temporary agency work, Transfer 22(4): 5215534. doi: https://doi.org/10.1177/1024258916667027. 
Berglund, T., Håkansson, K., Isidorsson, T., Alfonsson, J. (2017). Temporary employment and the future labor market status, Nordic Journal of Working Life Studies 7(2): 27-47. doi: http://dx.doi.org/10.18291/njwls.v7i2.81593.

Brandshaug, J. A. (2017). Vikarpool gir nye muligheter [Temp pool gives new opportunities]. Available at: https://sykepleien.no/meninger/innspill/2017/02/vikarpool-gir-nye-muligheter (Accessed November 2017).

Castle, N. G. (2009). Perceived advantages and disadvantages of using agency staff related to care in nursing homes, Journal of Gerontology 35(1): 28-36. doi: http://dx.doi.org/ 10.3928/00989134-20090101-03.

Cicellin, M., Iacono, M. P., Berni, A., Eposito, V. (2015). Dealing with resistance in temporary agency nurses. The role of fear in identity-building processes, Journal of Health Organization and Management 29 (3): 298-316. doi: https://doi.org/10.1108/JHOM-02-2013$\underline{0044 .}$

Coe, N., Johns, J., Ward, K. (2009). 'Managed flexibility': Labour regulation, corporate strategies and market dynamics in the Swedish temporary staffing industry, European Urban and Regional Studies 16(1): 65-85. doi: https://doi.org/10.1177/0969776408098933.

Coe, N., Johns, J., Ward, K. (2010). The business of temporary staffing agencies: a developing research agenda, Geography Compass 4(8): 1055-1068. doi: https://doi.org/10.1111/ j.1749-8198.2010.00360.x.

Dahle, R. (2011). En kamp om varme hender. Hvordan har det seg egentlig at vikarbyråene fikk fotfeste i helsevesenet? [A battle for warm hands. How did the TWAs gain a foothold in the health sector?]. Available at: https://sykepleien.no/2011/04/en-kamp-om-varmehender (Accessed November 2017).

Dahle, R, Midthus Østbye, M. (2007). Medisinske vikarbyråer. En sikkerhetsventil i et sårbart system? [Medical temp agencies. Safety valve in a vulnerable system?] Rapport 4/07, Oslo: NOVA.

De Ruyter, A., Kirkpatrick, I., Hoque, K., Lonsdale, C., Malan, J. (2008). Agency working and degradation of public service employment: the case of nurses and social workers, International Journal of Human Resources and Management 19(3): 432-445. doi: https:// doi.org/10.1080/09585190801895510.

Dolonen, K. A. (2015). Norge trenger flere ABIO sykepleiere [Norway needs more specialist nurses for operations, intensive care, anesthesia and childcare] https://sykepleien. no/2015/06/norge-trenger-flere-abio-sykepleiere (Accessed November 2017).

Dolonen, K. A. (2018). Sykehusene bruker milliarder på sykepleievikarer. [Hospitals spend billions on temporary nurses] Available at: https://sykepleien.no/2018/01/sykehusene-bruker-milliarder-pa-sykepleievikarer (Accessed June 2018).

Gautun, H., Øien, H., Bratt, C. (2016). Underbemanning er selvforsterkende. Konsekvenser av mangel på sykepleiere i hjemmesykepleien og sykehjem. [Understaffing is self-reinforcing. Consequences of nursing shortages in home care and nursing homes] Rapport 6/16, Oslo: NOVA.

Gottfried, H. (1992). In the margins: flexibility as a mode of regulation in the temporary help service industry, Work, Employment and Society 6(3): 443-460. doi: https://doi. org/10.1177/095001709263007.

Hirschman, A. O. (1970). Exit, Voice and Loyalty: Responses to Decline in Firms, Organizations and States, Cambridge, MA: Harvard University Press.

Hospital Partner (2017). Statistics on Agency Nurses in the Health Enterprises, Personal Communication.

Houseman, S. N., Kalleberg, A., Erickcek, G. A. (2003). The role of temporary agency employment in tight labor markets, Industrial and Labor Relations Review 57(1): 105-127. doi: https://doi.org/10.1177/001979390305700106. 
Jansson, A.B, Engström, Å. (2017). Working together. Critical care nurses experiences of temporary staffing within Swedish health care: a qualitative method, Intensive and Critical Care Nursing 41(1): 3-10. doi: http://dx.doi.org/10.1016/j.iccn.2016.08.010.

Jordhus-Lier, J., Coe, N., Bråthen, S. (2015). Contested growth: The development of Norway's temporary staffing industry, Geografiska Annaler Series B 97(1): 113-130. doi: http://dx.doi.org/10.1111/geob.12068.

Kiil, M. B. (2014). Midlertidighet som protest: Svenske sykepleiere og det norske arbeidsmarkedet. [Temping as protest. Swedish nurses and the Norwegian labour market.] Masteroppgave i samfunnsgeografi, Institutt for sosiologi og samfunnsgeografi, Universitetet i Oslo. Available at: https://www.duo.uio.no/handle/10852/56/browse?value=Kiil\%2C+Maiken+Bjerga\&type=author $($ Accessed December 2018).

Kiil, M. B., Knutsen, H. M. (2016). Agency by exit: Swedish nurses and the 'Not below 24, 000'movement, Geoforum 70: 105-114. doi: https://doi.org/10.1016/i.geoforum.2016.02.012.

Knutsen, H. M. (2014). Restructuring and socially managed flexibility in the Norwegian hotel industry, Norwegian Journal of Geography 68(5): 271-281. doi: https://doi.org/10 $.1080 / 00291951.2014 .965739$.

Lovdata (2008). Forskrift om lønns- og arbeidsvilkår i offentlige kontrakter. Available at: https://lovdata.no/dokument/SF/forskrift/2008-02-08-112 [Regulations on wage conditions and labor conditions in public contracts] (Accessed May 2018)

Lovdata (2014). Lov om arbeidsmiljø og stillingsvern mv (arbeidsmiljøloven). Available at: https://ovdata.no/dokument/NL/lov/2005-06-17-62/KAPITTEL 15\#\$14-9 [Law on working conditions and employment protection etc. (The Work Environment Act)] (Accessed November 2017).

May, J. H., Bazzolli, G. J., Gerland A. M. (2006). Hospitals' responses to nurse staffing shortages, Health Affairs 25(4): 316-323. doi: https://doi.org/10.1377/hlthaff.25.w316.

Ministry of Health and Social Care (2016). Spørsmål nr 662 til skriftlig besvarelse - oversikt over innleie fra vikarbyråer for å dekke nødvendig grunnbemanning [Written reply to question 662 - overview of labor hire from TWAs to cover necessary basic staffing]. Available at: https://www.stortinget.no/globalassets/pdf/dokumentserien/2015-2016/dok 15-201516-0662-vedlegg.pdf (Accessed November 2017).

NAV (2017). Bedriftsundersøkelsen våren 2017 [Company study, spring 2016]. Available at: https://www.nav.no/no/NAV+og+samfunn/Kunnskap/Analyser+fra+NAV/Arbeid+og+velferd/Arbeid + og + velferd/bedriftsunders $\% \mathrm{C} 3 \%$ B 8 kelsen Oslo: Arbeids- og velferdsdirektoratet (Accessed November 2017).

NHO Service (2017). Bemanningsbarometeret 2016. Bemanningsbransjens årsstatistikk [Annual statistics of the staffing sector 2016]. Available at: https://www.nhoservice.no/ contentassets/48fc5f7c12b04909a40b584ba93c085e/bemanningsbarometeret-2016.pdf (Accessed November 2017).

OECD (2015). International Migration Outlook. Changing patterns in the international migration of doctors and nurses to OECD countries, 105-182. http://dx.doi.org/10.1787/ migr outlook-2015-en.

Peck, J., Theodore, N., Ward, K. (2005). Constructing markets for temporary labour: employment liberalization and the internationalization of the staffing industry, Global Networks 5(1): 3-26. doi: https://doi.org/10.1111/j.1471-0374.2005.00105.x.

Purcell, J., Purcell, K, Tailby, S. (2004). Temporary work agencies: here today, gone tomorrow? British Journal of Industrial Relations 42(4): 705-725. doi: https://doi.org/10.1111/ j.1467-8543.2004.00337.x.

Royal College of Nursing and HCL Nursing (2016). Agency Nursing under the microscope: understanding flexibility in the NHS. RCN Research Paper, September. Available at: https:// www.rcn.org.uk/professional-development/publications/pub-005801 (Accessed November 2017). 
Seo, S., Spetz, J. (2014). Demand for temporary agency nurses and nursing shortages, Journal of Health Care Organization, Provision and Financing 50(3): 216-228. doi: https://doi. org/10.1177/0046958013516583.

Silver, B. (2003). Forces of Labor: Workers' Movements and Globalization Since 1870, Cambridge, MA: Cambridge University Press.

Skjælaaen, C. J. (2010). Innleie av sykepleiere i sykehus. Fra nødløsninger til vikarpraksis [Hire of nurses in hospitals. From emergency solutions to substitute practice], $\mathrm{PhD}$ dissertation, University of Bergen. Available at: https://brage.bibsys.no/xmlui/handle/11250/165317 (Accessed November 2017).

Skjøstad, O., Hjemås, G, Beyrer, S. (2017). 1 av 5 nyutdanna sykepleiere jobber ikke i helsetjenesten [1 out of 5 newly graduated nurses not working in the health sector.] Available at: https://www.ssb.no/helse/artikler-og-publikasjoner/1-av-5-nyutdanna-sykepleiere-jobber-ikke-i-helsetienesten (Accessed November 2017).

Smith, C. (2006). The double indeterminacy of labour power, Work, Employment and Society 20(2): 389-402. doi: https://doi.org/10.1177/0950017006065109.

SSB (2011-2014). Innvandrere og ikke-bosatte 15-74 år med helse og sosialfaglig utdannelse sysselsatt etter landbakgrunn. [Immigrants and non-residents with education in health and social care, employed and according to country of origin]. (Accessed June 2015, not available anymore on ssb.no)

SSB (2015-2017). Statistics on labour hire, $4^{\text {th }}$ quarter for the period 2010 to 2016, Personal Communication.

Stavanger Aftenblad (2010). Slik får de nok pleiere [This is how they get enough nurses]. Available at: https://www.nsf.no/Content/876865/Slik32f-27r32de32nok32pleiere.pdf. (Accessed November 2017).

Stølen, N. M., Texmon, I. (2012). Betydelig underdekning av helsepersonell i 2035. [Considerable shortage of health personnel by 2035]. Available at: https://www.ssb.no/forskning/mikrookonomi/arbeidsmarked/betydelig-underdekning-av-helsepersonell-i-2035 (Accessed November 2017).

Svalund, J., Peixoto, A., Dølvik, J. E., Jesnes, K. (2018). Hiring of flexible and fixed-term workers in five Norwegian and Swedish industries, Nordic Journal of Working Life Studies 8 (3): 47-67. doi: https://doi.org/10.18291/njwls.v8i3.109540.

Tailby, S. (2005). Agency and bank nursing in the UK National Health Service, Work, Employment and Society 19(2): 369-389. doi: https://doi.org/10.1177/0950017005053178.

The Research Council of Norway (2014). Unge sykepleiere vil jobbe heltid. [Young nurses want to work full time] Available at: https://www.forskningsradet.no/prognett-finnut/ Nyheter/Unge sykepleiere vil jobbe heltid/1253997437517\&lang=no (Accessed November 2017).

Wright, E. O. (2000). Working-class power, capitalist class interests and class compromise. American Journal of Sociology 105(44): 9571002. doi: https://doi.org/10.1086/210397.

Yin, R. K. (2014). Case Study Research: Design and Methods. $5^{\text {th }}$ ed, Los Angeles: Sage.

Zampoukos, K., Knutsen, H. M., Kiil, M. B., Olofsdotter, G. (2018). Mobile with an agency: negotiating the spatiotemporalities of the temp migrant worker, Geoforum 93: 40-47. doi: https://doi.org/10.1016/j.geoforum.2018.05.003.

\section{Notes}

1 In Norway, the state owns four regional health enterprises that have responsibility for hospitals; municipalities are responsible for homecare and nursing homes.

2 Maiken Bjerga Kiil, University of Oslo, Norway, has interviewed the Swedish nurses. 
3 HINAS was transferred to Hospital Procurement Health Enterprises of Hospital Partner in 2016. The agreement is still known as the HINAS agreement.

4 The figure includes midwives and public health nurses with additional formal training.

5 Rota work refers to the composition of shifts (morning, evening, night) that the nurses are obliged to take and how frequently they have to work in the week-ends.

6 A new system of data collection was introduced in 2015, so the 2016 figure is not directly comparable with previous years; see https:/www.ssb.no/arbeid-og-lonn/naermere-om-forholdet-mellom-gammelog-ny-statistikk.

7 Information from an on-going student project, Department of Sociology and Human Geography, University of Oslo.

8 See website on temping in the Nordic countries from DNC: https://dsr.dk/loen-og-arbejdsvilkaar/ overenskomster-og-aftaler/private-aftaler/vikarjob-i-norden.

9 NOK 100 = Euro 9.40, October 2017. 